\title{
REGIONAL DIFFERENCES IN AGRICULTURAL PRODUCTION POTENTIAL IN THE EUROPEAN UNION MEMBER STATES
}

\author{
Adam Pawlewicz ${ }^{1}$, Ph.D; Katarzyna Pawlewicz ${ }^{2}$, Ph.D \\ ${ }^{1}$ Department of Agrotechnology, Agricultural Production Management and Agribusiness, University of Warmia \\ and Mazury in Olsztyn, Poland, \\ ${ }^{2}$ Department of Planning and Spatial Engineering, University of Warmia and Mazury in Olsztyn, Poland
}

\begin{abstract}
The article discusses differences in agricultural production potential and resource productivity (land, labour and capital) in the European Union countries. The aim of study was to evaluate regional differences in the productive potential of the EU agri-food sector. The analysis was conducted based on EUROSTAT data for 2013. In the first part of the study, selected parameters describing the productive potential of the agri-food sector in the EU countries were identified based on an analysis of statistical data. Then data were analysed with the use of selective descriptive statistics, including the arithmetic mean, median, minimum value, maximum value, as well as measures of statistical dispersion - range and coefficient of variation (CV). The results revealed considerable disproportions in productive potential of agriculture across the EU, which can be attributed to the characteristic features of the evaluated countries. The greatest variations were noted in land productivity, whereas the differences in capital and labour productivity were far less pronounced. The countries that joined the EU in 2004 and 2007 differed considerably from the EU-15 Member States in land, labour and capital productivity.
\end{abstract}

Key words: production capacity, productive potential, agriculture, differences, EU

JEL code: J43, O18, R1, Q12

\section{Introduction}

The agri-food sector is one the largest sectors of the economy which caters to the basic life needs of the human population (Sambotin D., Toader C. S., Ioana M. I., 2013). Agriculture, food processing, commerce and distribution play pivotal roles in the food supply chain around the world. The agri-food sector is unique in that the demand for food is limited and the rate of increase in resource productivity is higher than the rate of increase in demand. The development of the agrifood sector is driven mainly by profit maximization (Kremen C., Iles A., Bacon C., 2012; Cassman K.G.,2016) and consumer demand associated with utility maximization (Chavas J.P., 2017). Legal regulations and state support also play an important role in agricultural development. The growing volume of international trade in food and agricultural products testifies to the dynamic development of the agri-food sector (Borawski P., Beldycka-Borawska A., 2016). However, recent years have demonstrated that sustainability is as important as profit maximization in agricultural practice (Borawski P., Pawlewicz A.,2006; Brodzinska K., 2008).

The agricultural sector in the European Union has undergone considerable changes in recent years. The above resulted mainly from the stimulating influence of Common Agricultural Policy payments on the competitiveness of the EU agricultural sector as well as growing levels of economic interdependence in the EU. Globalization and improved access to foreign markets have enabled the European agri-food sector to compete with global food producers. Despite institutional support, Europe's agri-food producers have to maximize their productivity to maintain their competitive edge. In simple terms, competitiveness can be defined as the ability to gain supremacy over market rivals striving for the same goals (Ajitabh A., Momaya K.S., 2003). Companies have to build their productive potential in order to effectively compete with rivals and acquire a competitive advantage on the market (Feurer R., Chaharbaghi K., 1994). Production capacity determines a company's competitive edge in the agri-food sector. Productivity is one of the factors that are taken into account in assessments of market performance (Zepeda L., 2001). Productivity can be defined as the maximum output that can be generated and supplied by a company using the 
available land, labour and capital. A company's productivity is assessed based on the effectiveness of resource use. In the resource-based theory, productive resources are regarded as the basic determinant of competitive advantage (Grant R.M., 1991). Therefore, the aim of this study was to evaluate regional differences in the productive potential of the EU agri-food sector.

In the first part of the study, selected parameters describing the productive potential of the agri-food sector in the EU countries were identified based on an analysis of statistical data. Production capacity was determined in view of the basic productive resources (land, labour and capital), absolute values (measures), relative values (indicators) and their correlations based on the following indicators: global production per 1 ha of agricultural area, global production per employee, global production per $1 €$ of gross fixed assets, gross fixed assets per 1 ha of agricultural area, agricultural area per employee, and gross fixed assets per employee. The analysis was conducted based on Eurostat data. Not all countries could be compared due to the lack of the relevant data (information about gross fixed assets was not available for Spain and Cyprus). A vertical analysis was performed on a comprehensive set of data for 2013.

Data were analysed with the use of selective descriptive statistics, including the arithmetic mean, median, minimum value, maximum value, as well as measures of statistical dispersion range and coefficient of variation (CV).

\section{Research results and discussion}

In agriculture, productive potential is evaluated based on productive resources: land, labour and capital. The relevant data for the EU Member States are presented in Table 1. The values of the coefficients of variation point to highly significant differences in the share of productive resources in agricultural outputs between the analysed countries. The greatest variations were observed in the number of farm employees (CV over $140 \%$ ). Similar results were reported by Golebiewska (2013). In 2013, Poland (nearly 2 million) and Romania (over 1.5 million) ware characterized by one of the highest levels of employment in the agri-food sector. By comparison, the value of this parameter was more than $50 \%$ lower in Italy (about 816 thousand), France (724 690) and Germany (522 730). The lowest employment in the agri-food sector was noted in Latvia (82 090), Slovenia (82 450), Czech Republic (105 080) and Austria (111 160). It is worth noting that these disproportions are considerably smaller when the average numbers of farmworkers are compared (CV about $54 \%$ ). The highest average number of workers per farm was noted in the Czech Republic (4 employees). The discussed parameter was nearly $50 \%$ lower in the Netherlands (2.3), Slovakia (2.2) and Germany (1.8). The lowest average employment per farm was recorded in Romania (0.4), Malta (0.5), Greece (0.7), Austria (0.8) and Italy (0.8).

Capital is also a key resource that influences workforce productivity, agricultural productivity and competitiveness. An analysis of gross fixed assets in the EU agri-food sector revealed significant disproportions (CV over $133 \%$ ). Capital investments were highest in France (12 934.7 million $€$ ), Germany (9 547.0 million $€$ ), Italy (9 225.2 million $€$ ) and lowest in Malta (14.9 million $€)$, Luxembourg (210.8 million $€$ ), Slovenia (237.6 million $€$ ) and Estonia (287.3 million $€$ ).

Highly significant variations were also noted in the average gross value of fixed assets in agriculture (CV 118.10\%). This parameter was highest in Luxembourg (101336.5 $€$ ) and the Netherlands (70 $598.7 €$ ), and it was $50 \%$ lower in the Czech Republic (54 $364.2 €$ ) and United Kingdom (45 $783.6 €$ ). The average gross value of fixed assets was relatively low in Romania $(597.5 €)$, Greece ( $1446.6 €$ ), Malta (1 595.1 $€$ ) and Hungary (1 $861.1 €)$. These results point to 
low levels of investment in agricultural production, in particular in countries with a high proportion of small farms in the agri-food sector (Byerlee D., De Janvry A., Sadoulet E., 2009).

Land is the most important productive resource in agriculture. In 2013, considerable variations in utilized agricultural area were noted across the EU (CV over $117 \%$ ). This parameter was highest in France (27 739430 ha), the United Kingdom (17 326990 ha), Germany (16 699580 ha) and Poland (14 $409870 \mathrm{ha}$ ). Utilized agricultural area exceeded 10 million ha in Romania. The evaluated parameter was lowest in Malta (10 880 ha), Luxembourg (131 040 ha), Slovenia (485 $760 \mathrm{ha}$ ) and Estonia (957 $510 \mathrm{ha}$ ).

Smaller but statistically significant variations were observed in average utilized agricultural area (CV 89,4\%). The largest farms were situated in the United Kingdom (average utilized agricultural area of 63.1 ha per farm), Sweden (51.2 ha), Denmark (49.3 ha) and Estonia (43.4 ha). Slovenian farms were characterized by relatively small average utilized agricultural area (5.9 ha). A similar situation was in Poland (7.5 ha), Romania ( $8.4 \mathrm{ha}$ ) and Croatia ( $8.8 \mathrm{ha})$. It should be noted that the above results are influenced by the number of farms and utilized agricultural area. Microeconomic and macroeconomic factors, such as the size of the country, population, export potential and quality of agricultural land, also play an important role. Low average farm area and relatively high employment in a farm limit the accumulation of capital and investments in agricultural production (Wicka A., 2012).

The analysis produced some interesting results ${ }^{1}$. The majority of EU-15 countries were characterized by a predominance of large farms with fewer workers and high levels of investment in fixed assets. In contrast, countries that joined the EU in 2004 and 2007, such as Poland and Romania, and countries with small utilized agricultural area, such as Malta and Luxembourg, had a higher number of small farms with higher employment and low levels of investment in fixed assets.

Agricultural competitiveness is largely determined by farmers' ability to maximize their resource productivity and overall productivity. Productive potential is a quantitative measure of the relationship between agricultural inputs and outputs. Agricultural outputs were measured based on global production values for every analysed productive resource (Table 2). In 2013, significant regional differences were observed in global agricultural production in the EU (CV around $150 \%$ ). It should be noted that the absolute gross value of fixed assets is highly correlated with farm area. The gross value of fixed assets was highest in countries with the highest utilized agricultural area, mostly the EU-15 countries, including Italy (33 024.4 million $€$ ), France (26 381.3 million $€$ ), Germany (21 993.8 million $€$ ), United Kingdom (10 835.4 million $€$ ), the Netherlands (10 194.1 million $€$ ). In the group of countries that joined the EU in 2004 and 2007, the evaluated parameter was high in Poland (9 398.1 million $€$ ) and Romania (7 621.3 million $€$ ), which could be attributed to large agricultural area and a high number of farms.

The gross value of fixed assets was lowest in Malta (56.2 million $€$ ), Luxembourg (103.2 million $€)$, Latvia (254.8 million $€$ ), Estonia (332,8 million $€$ ), Slovenia (407.5 million $€$ ) and Slovakia (597.6 million $€$ ). Lower values of the analysed parameter were observed in countries characterized by a smaller number of farms and small agricultural area, mostly countries that joined the EU in 2004 and 2007.

${ }^{1}$ Vertical and horizontal analyses will be carried out in future research. 
Table 1

Basic data relating to agricultural production potential in the EU Member States in 2013

\begin{tabular}{|c|c|c|c|c|c|c|c|}
\hline Specification & $\begin{array}{c}\text { NoF } \\
\text { number }\end{array}$ & $\begin{array}{c}\text { UAA } \\
\text { ha }\end{array}$ & $\begin{array}{c}\text { AUAA } \\
\text { ha }\end{array}$ & $\begin{array}{c}E \\
\text { number }\end{array}$ & $\begin{array}{c}\text { AEpF } \\
\text { number }\end{array}$ & $\begin{array}{l}\text { GVoFA } \\
\text { mIn } \mathbf{C}\end{array}$ & $\begin{array}{c}\text { AGVoFA } \\
\boldsymbol{C}\end{array}$ \\
\hline Belgium & 37760 & 1307900 & 34.6 & 56730 & 1.5 & 1149.7 & 30447.6 \\
\hline Bulgaria & 254410 & 4650940 & 18.3 & 320230 & 1.3 & 532.8 & 2094.1 \\
\hline Czech Republic & 26250 & 3491470 & 133.0 & 105080 & 4.0 & 1427.1 & 54364.2 \\
\hline Denmark & 38280 & 2619340 & 68.4 & 53170 & 1.4 & 1438.3 & 37574.2 \\
\hline Germany & 285030 & 16699580 & 58.6 & 522730 & 1.8 & 9547.0 & 33494.7 \\
\hline Estonia & 19190 & 957510 & 49.9 & 22060 & 1.2 & 287.3 & 14971.3 \\
\hline Ireland & 139600 & 4959450 & 35.5 & 163690 & 1.2 & 799.9 & 5730.2 \\
\hline Greece & 709500 & 4856780 & 6.9 & 463860 & 0.7 & 1026.4 & 1446.6 \\
\hline France & 472210 & 27739430 & 58.7 & 724690 & 1.5 & 12934.7 & 27391.8 \\
\hline Croatia & 157440 & 1571200 & 10.0 & 175050 & 1.1 & 387.4 & 2460.4 \\
\hline Italy & 1010330 & 12098890 & 12.0 & 816920 & 0.8 & 9225.2 & 9130.9 \\
\hline Latvia & 81800 & 1877720 & 23.0 & 82090 & 1.0 & 394.5 & 4823.1 \\
\hline Lithuania & 171800 & 2861250 & 16.7 & 144770 & 0.8 & 682.9 & 3975.0 \\
\hline Luxembourg & 2080 & 131040 & 63.0 & 3530 & 1.7 & 210.8 & 101336.5 \\
\hline Hungary & 491330 & 4656520 & 9.5 & 433700 & 0.9 & 914.4 & 1861.1 \\
\hline Malta & 9360 & 10880 & 1.2 & 4450 & 0.5 & 14.9 & 1595.1 \\
\hline Netherlands & 67480 & 1847570 & 27.4 & 153310 & 2.3 & 4764.0 & 70598.7 \\
\hline Austria & 140430 & 2726890 & 19.4 & 111160 & 0.8 & 2351.0 & 16741.4 \\
\hline Poland & 1429010 & 14409870 & 10.1 & 1918550 & 1.3 & 4196.3 & 2936.5 \\
\hline Portugal & 264420 & 3641590 & 13.8 & 323470 & 1.2 & 883.5 & 3341.2 \\
\hline Romania & 3629660 & 13055850 & 3.6 & 1552630 & 0.4 & 2168.9 & 597.5 \\
\hline Slovenia & 72380 & 485760 & 6.7 & 82450 & 1.1 & 237.7 & 3283.4 \\
\hline Slovakia & 23570 & 1901610 & 80.7 & 50600 & 2.2 & 404.1 & 17145.5 \\
\hline Finland & 54400 & 2282400 & 42.0 & 57550 & 1.1 & 1594.0 & 29301.5 \\
\hline Sweden & 67150 & 3035920 & 45.2 & 59320 & 0.9 & 1707.0 & 25420.6 \\
\hline United Kingdom & 183040 & 17326990 & 94.7 & 274520 & 1.5 & 8380.2 & 45783.7 \\
\hline \multicolumn{8}{|c|}{ Descriptive statistics } \\
\hline arithmetic mean & 378381 & 5815551.9 & 36.3 & 333704.2 & 1.3 & 2602.3 & 21071.0 \\
\hline median & 140015 & 2948585.0 & 25.2 & 149040.0 & 1.2 & 1088.0 & 12051.1 \\
\hline minimum value & 2080 & 10880.0 & 1.2 & 3530.0 & 0.4 & 14.9 & 597.5 \\
\hline maximum value & 3629660 & 27739430.0 & 133.0 & 1918550.0 & 4.0 & 12934.7 & 101336.5 \\
\hline standard deviation & 744419.6 & 6821986.6 & 32.4 & 469150.1 & 0.7 & 3486.2 & 24883.9 \\
\hline variance & $5.54 \mathrm{E}+11$ & $4.65 E+13$ & $1.05 \mathrm{E}+03$ & $2.20 \mathrm{E}+11$ & $\begin{array}{c}5.09 \mathrm{E}- \\
01\end{array}$ & $1.22 \mathrm{E}+07$ & $6.19 E+08$ \\
\hline $\begin{array}{l}\text { coefficient of } \\
\text { variation }\end{array}$ & 196.7 & 117.3 & 89.4 & 140.6 & 54.4 & 133.0 & 118.1 \\
\hline
\end{tabular}

MoF - number of farms; UAA - utilized agricultural areal; AUAA - average utilized agricultural area; E- employment; AEpF average employment per farm; GVoFA - gross value of fixed assets; AGVoFA - average gross value of fixed assets Source: authors' calculations based on Eurostat Database (http://ec.europa.eu/eurostat/data/database)

The productive potential of the EU countries can be more reliably compared based on relative values. The average gross value of fixed assets per farm was also characterized by significant regional variation ( $\mathrm{CV}$ over $110 \%$ ). High values of the above parameter were noted in Western Europe, including in the Netherlands (average $151068.8 €$ ), Germany (77 $163.1 €$ ), Denmark (73 $154.6 €$ ), Belgium ( $60726.2 €$ ), the United Kingdom (59 197.0 $€$ ) and France (55 $867.7 €$ ). The average gross value of fixed assets per farm was lowest in Romania ( $2099.7 €$ ). The analysed 
parameter was also very low in Poland (6 576.6 $€$ ) and Latvia (3 $114.6 €)$, Slovenia (5 $629.5 €)$, Hungary (5 908.1) and Malta (6 007.5 €).

Table 2

Productivity of agricultural resources in the EU Member States in 2013

\begin{tabular}{|c|c|c|c|c|c|}
\hline Specification & $\begin{array}{c}\text { GPiA } \\
\text { million } \mathbf{C}\end{array}$ & $\begin{array}{c}\text { AVoGP } \\
\boldsymbol{C}\end{array}$ & $\begin{array}{c}\text { GPp1haoUAA } \\
\text { C }\end{array}$ & $\begin{array}{c}\text { GPpE } \\
\text { C }\end{array}$ & $\begin{array}{c}\text { GPp1 CoGFA } \\
\text { C }\end{array}$ \\
\hline Belgium & 2293.0 & 60726.2 & 1753.2 & 40419.9 & 2.0 \\
\hline Bulgaria & 1694.4 & 6660.0 & 364.3 & 5291.1 & 3.2 \\
\hline Czech Republic & 1426.6 & 54344.8 & 408.6 & 13575.9 & 1.0 \\
\hline Denmark & 2800.4 & 73154.7 & 1069.1 & 52668.1 & 2.0 \\
\hline Germany & 21993.8 & 77163.1 & 1317.0 & 42074.7 & 2.3 \\
\hline Estonia & 332.8 & 17341.8 & 347.6 & 15085.7 & 1.2 \\
\hline Ireland & 2001.4 & 14336.8 & 403.6 & 12226.9 & 2.5 \\
\hline Greece & 4964.2 & 6996.7 & 1022.1 & 10701.8 & 4.8 \\
\hline France & 26381.3 & 55867.7 & 951.0 & 36403.6 & 2.0 \\
\hline Croatia & 1006.5 & 6392.6 & 640.7 & 5749.5 & 2.6 \\
\hline Italy & 33024.4 & 32686.8 & 2729.5 & 40425.6 & 3.6 \\
\hline Latvia & 254.8 & 3114.6 & 135.7 & 3103.5 & 0.7 \\
\hline Lithuania & 1057.8 & 6157.2 & 369.7 & 7306.8 & 1.6 \\
\hline Luxembourg & 103.2 & 49629.8 & 787.8 & 29243.6 & 0.5 \\
\hline Hungary & 2902.8 & 5908.1 & 623.4 & 6693.2 & 3.2 \\
\hline Malta & 56.2 & 6007.5 & 5168.2 & 12636.0 & 3.8 \\
\hline Netherlands & 10194.1 & 151068.8 & 5517.6 & 66493.5 & 2.1 \\
\hline Austria & 2736.0 & 19482.8 & 1003.3 & 24612.9 & 1.2 \\
\hline Poland & 9398.1 & 6576.6 & 652.2 & 4898.5 & 2.2 \\
\hline Portugal & 2538.9 & 9601.7 & 697.2 & 7848.9 & 2.9 \\
\hline Romania & 7621.3 & 2099.7 & 583.8 & 4908.6 & 3.5 \\
\hline Slovenia & 407.5 & 5629.5 & 838.8 & 4941.9 & 1.7 \\
\hline Slovakia & 597.6 & 25355.5 & 314.3 & 11810.9 & 1.5 \\
\hline Finland & 1277.0 & 23475.0 & 559.5 & 22190.1 & 0.8 \\
\hline Sweden & 1625.5 & 24206.4 & 535.4 & 27401.6 & 1.0 \\
\hline United Kingdom & 10835.4 & 59197.0 & 625.4 & 39470.4 & 1.3 \\
\hline arithmetic mean & 5751.0 & 30891.6 & 1131.5 & 21084.0 & 2.1 \\
\hline median & 2147.2 & 18412.3 & 646.4 & 13105.9 & 2.0 \\
\hline minimum value & 56.2 & 2099.7 & 135.7 & 3103.5 & 0.5 \\
\hline maximum value & 33024.4 & 151068.8 & 5517.6 & 66493.5 & 4.8 \\
\hline standard deviation & 8612.2 & 34178.4 & 1348.0 & 17368.0 & 1.1 \\
\hline variance & $7.42 \mathrm{E}+07$ & $1.17 \mathrm{E}+09$ & $1.82 \mathrm{E}+06$ & $3.02 E+08$ & 1.2 \\
\hline coefficient of variation & 149.8 & 110.6 & 119.1 & 82.4 & 51.9 \\
\hline
\end{tabular}

GPiA - global production in agriculture, AVoGP - average value of global production; GPp1haoUAA - global production per 1 ha of agricultural area; GPpE - global production per employee; GPp1€oGFA - global production per $1 €$ of gross fixed assets Source: authors' calculations based on Eurostat Database (http://ec.europa.eu/eurostat/data/database)

Resource productivity was evaluated based on the calculated indicators of productivity. Productivity is the main driver of growth in agriculture (Ball V.E., Bureau J.C., Nehring R., Somwaru A., 1997). Higher productivity decreases costs, increases the supply of cheaper goods and services, stimulates market growth and increases consumers' purchasing power (Golebiewska B., 2013).

An analysis of resource productivity revealed the greatest differences in land productivity. In this category, the coefficient of variation exceeded $119 \%$, and it was nearly $40 \%$ higher in 
comparison with labour productivity ( $\mathrm{CV} 82.4 \%$ ) and more than twice higher in comparison with capital productivity (CV $51.9 \%$ ). The Netherlands (5 $517.6 €$ ), Malta (5 $168.2 €$ ) and Italy (2 $729.5 €$ ) were the EU's leaders in terms of effective land use. The lowest land productivity was observed in Latvia $(135.7 €)$, Slovakia $(314.3 €)$, Estonia $(347.6 €)$, Bulgaria $(364.3 €)$ and Lithuania $(369.7 €)$.

The analysed countries also differed significantly in labour productivity in the agri-food sector. The highest values of the above parameter were noted in the Netherlands (66 $493.5 €$ ), Denmark (52 668.1 $€$ ), Germany (42 $074.9 €$ ), Italy (40 $425.6 €$ ) and Belgium (40 $419.9 €$ ). In the group of countries that joined the EU in 2004 and 2007, including Latvia ( $3103.5 €$ ), Poland (4 $898.5 €$ ), Romania (4 $908.6 €$ ) and Slovenia (4 $941.9 €$ ), labour productivity was up to 20 -fold lower. Those variations can be attributed mainly to differences in farm size and employment, and, to a lesser extent, to the absolute measures of agricultural outputs in the analysed countries.

The smallest but considerable differences were observed in the productivity of capital engaged in agricultural production. An investment of $1 €$ in fixed assets generated the greatest benefits in Greece $(4.8 €)$, Malta $(3.8 €)$, Italy $(3.6 €)$, Romania $(3.5 €)$ and led to the smallest increase in agricultural production in Luxembourg $(0.5 €)$, Latvia $(0.7 €)$, Finland $(0.8 €)$, Sweden $(1.0 €)$. It should be noted that low agricultural productivity is associated with diminishing marginal productivity of capital (Thirtle C., Lin Lin L., Holding J., Jenkins L., Piesse J. 2004).

\section{Conclusions, proposals, recommendations}

- The results of the presented analysis point to significant regional differences in the productive potential of agriculture in the EU Member States. Those discrepancies can be attributed to variations in geographic and natural conditions, type of agricultural production, fragmentation of agricultural land, population and economic development. Agricultural competitiveness is largely determined by farmers' ability to maximize resource productivity and the overall productivity of agricultural systems.

- The greatest disproportions were noted in land productivity, whereas the differences observed in capital and labour productivity were less pronounced. This indicates that worker productivity and investments in fixed assets are the key determinants of productive potential as well as competitiveness in the agri-food sector.

- The presented analysis produced interesting results. The most satisfactory values of the evaluated indicators were observed in the EU-15 countries which are characterized by the highest productive potential of agriculture (France, Germany, Italy). The analysed variables and the lowest productive potential were noted in the countries that joined the EU in 2004 and 2007 (Romania, Poland, Latvia, Slovenia, Hungary). These observations indicate that greater support should be channelled to the new Member States to eliminate disproportions in the EU agri-food sector. However, effective restructuring programs should also be implemented in those countries to improve their competitiveness. Such measures would contribute to a decrease in the number of farms and, consequently, to an increase in average farm area. These transformation processes would ultimately increase labour and capital productivity in agriculture.

\section{Bibliography}

1. Ajitabh, A., Momaya, K. S. (2003). Competitiveness of Firms: Review of Theory, Frameworks and Models. Singapore Management Review, Volume 26. No. 1. pp. 45-61. 
2. Ball, V. E., Bureau, J. C., Nehring, R., Somwaru, A. (1997). Agricultural Productivity Revisited. American Journal of Agricultural Economics, No. 79(4). pp. 1045-1063.

3. Borawski, P., Beldycka-Borawska, A. (2016). Polski handel zagraniczny artykułami rolno-spożywczymi i jego prognoza (Polish international trade of agri food products and its prognosis). Zeszyty Naukowe Szkoly Glownej Gospodarstwa Wiejskiego w Warszawie. Problemy Rolnictwa Swiatowego. No. 16(XXXI), Volume 1. pp. 48-59.

4. Borawski, P., Pawlewicz, A. (2006). Efektywnosc ekonomiczna indywidualnych gospodarstw rolnych w aspekcie zrownoważonego rozwoju obszarów wiejskich na przykładzie województwa warmińskomazurskiego (Economic efficiency of individual farms in rural areas sustainable development aspect on the example of Warmia and Mazury Province). Zeszyty Naukowe Akademii Rolniczej we Wroclawiu. No. 540. pp. 91-97.

5. Brodzinska, K. (2008). Conditions of Agri-environmental Programme Implementation in Poland. Economic Science for Rural Development. No. 16. pp. 27-32.

6. Byerlee, D., De Janvry, A., Sadoulet, E. (2009). Agriculture for Development: Toward a New Paradigm. Annual Review of Resource Economics, No. 1(1). pp. 15-31.

7. Cassman, K. G. (2016). Long-term Trajectories: Crop Yields, Farmland, and Irrigated Agriculture. Economics Reviews, Special Issue, pp. 21-46.

8. Chavas, J.P. (2017). On Food Security and the Economic Valuation of Food. Food Policy. Volume 69. pp 5867

9. Feurer, R., Chaharbaghi, K. (1994). Defining Competitiveness: a Holistic Approach. Management Decision, No. 32(2). pp. 49-58.

10. Golebiewska, B. (2013). Trends of Changes in Resources and Work Performance in Polish Agriculture in Comparison with the Selected EU countries. Economic Science for Rural Development. No. 30 pp. 99-103.

11. Grant, R. M. (1991). The Resource-based Theory of Competitive Advantage: Implications for Strategy Formulation. California management review, No. 33(3). pp. 114-135.

12. Kremen, C., Iles, A., Bacon, C. (2012). Diversified Farming Systems: an Agroecological, Systems-based Alternative to Modern Industrial Agriculture. Ecology and Society. No. 17(4): art. 44. pp. 1-19.

13. Sambotin, D., Toader, C. S., Ioana, M. I. (2013). Development and Potential of Agriculture in the Western Part of Romania. Economic Science for Rural Development. No. 30. pp. 87-90.

14. Thirtle, C., Lin Lin, L., Holding, J., Jenkins, L., Piesse, J. (2004). Explaining the Decline in UK Agricultural Productivity Growth. Journal of Agricultural Economics, No. 55(2). pp. 343-366.

15. Wicka, A. (2012). Polish Agriculture against Selected States of the European Union. Economic Science for Rural Development, No. 29. pp. 140-147.

16. Zepeda, L. (2001). Agricultural Investment, Production Capacity and Productivity. in: Agricultural Investment and Productivity in Developing Countries. Edited by Lydia Zepeda. FAO Economic and Social Development Paper, No. 148, pp. 3-20. 